\title{
IQRA; ANTARA ILMU DAN TAUHID
}

\section{Oleh : Syaiful Rahmat Panggabean}

\section{Mukaddimah}

Kata "Iqra" adalah kata yang tercakup dalam wahyu pertama yang disampaikan pada nabi Muhammad melalui malaikat Jibril. Secara mafhum almuwafaqah termuat makna "belajar "dalam kata tersebut. Biasanya ayat pertama dalam surat al-Alaq ini menjadi referen utama dalam menyampaikan perintah belajar kepada kaum muslim.

Di sisi lain jika dicermati secara gramatikal eksistensi dan posisi kata “iqra" adalah transitif atau yang membutuhkan objek, namun pada ayat ini ia tidak berobjek bahkan disambut dengan kalimat berikutnya "dengan nama Tuhanmu”. Walaupun demikian Allah tidaklah menjadikan dan menciptakan sesuatu tanpa hikmah di balik semua.

Iqra adalah bentuk kata perintah (amr) dari qara'a yang berarti “membaca”. Kata qara'a ini berbeda dengan kata tala dalam makna (sense) namun sama dalam arti (meaning) yaitu membaca.

Dalam perspektif semantis, qara'a bermakna 'membaca dengan memahami' sedangkan tala "membaca tanpa memahami apa yang dibaca". Dengan demikian timbul istilah Musabaqah Tilawatil Quran bukan Musabaqah Qira'atil Quran karena tidak semua qari dapat memahami apa yang dibacanya. Di samping itu kata qara'a juga mengandung makna "membaca hanya satu kata" sedangkan tala "membaca lebih dari satu kata". 


\section{Iqra Jembatan Profesionalisme Keilmuan}

Kata Iqra yang tidak berobjek dalam surat 'Alaq jika dikorelasikan dengan ayat-ayat lain, maka akan terungkap objek apa yang akan diiqra, misalnya "apakah mereka tidak membaca dan memahami bagaimana unta diciptakan, bagaimana langit ditinggikan, bagaimana gunung ditegakkan, dan bagaimana bumi ini dibentangkan” (Q.S. 88: 17-20). Tanpa membaca alam sekitar ini mungkin tidaklah timbul Biologi, Zoologi, Astronomi, Fisika dan sebagainya.

Dengan perintah iqra yang yang bermakna membaca satu kata, manusia berupaya membaca, memahami dan mendalami satu aspek tanpa mengabaikan aspek lain. Karena Allah dalam mengajari manusia memerlukan media dan sarana yaitu Qolam. Begitu juga kiranya manusia dalam meningkatkan kemampuan disiplin keilmuannya dengan menjadikan disiplin ilmu lain sebagai sarana pengembangan wawasan keilmuan yang digeluti. Seorang pakar hukum syariat akan mengalami kendala dengan ketidaktahuannya tentang undang-undang positif, ilmu sosiologi, antroplogi dan lain sebagainya sebagai penunjang penerapan ilmunya dalam masyarakat sehingga tidak terpenjara dalam keilmuan yang monoton tanpa pertimbangan aspek-aspek lain. Hal ini bukan berarti legalisasi inter-disipliner keilmuan yang mengundang kehancuran dan kerancuan, ekonom bicara politik, politikus berbicara ekonomi, apa yang terjadi? Mari kita coba bertanya pada keadaan negara Indonesia yang tercinta ini.

Dengan kata lain kata iqra memerintahkan profesionalisme dalam segala hal, sehingga kita termasuk manusia yang otentik (dalam istilah psikologi). 


\section{Iqra dan Monotheis (Tauhid)}

Berlaku profesional dan pakar dalam segala aspek itulah harapan kata "Iqra", namun tidak boleh terlepas dari kalimat setelah iqra yaitu "dengan nama Tuhanmu". Jadilah seorang ekonom dengan nama Tuhanmu, jadilah pakar biologi, jadilah pakar fisika dengan nama Tuhanmu, jadilah pengacara atas nama Tuhanmu. Dengan berlandaskan "nama Tuhanmu" (baca: keimanan dan ketaqwaan), maka seorang pakar tidak akan menggunakan ilmunya untuk kerusakan bagi manusia. Seorang ekonom atau akuntan tidak akan menukangi angka untuk mendapatkan keuntungan dari sebuah laporan keuangan, seorang pengacara tidak akan membenarkan yang salah atau menyalahkan yang benar hanya karena bayaran.

Dengan ketekunan untuk bergelut dalam satu disiplin keilmuan tak jarang seorang pakar harus mengakui keagungan satu kekuatan gaib (baca: Tuhan) pencipta dunia dan isinya yang serba sempurna dan kemahakuasaan-Nya. Dengan menyaksikan keagungan ciptaan-Nya akan terlantun di bibir seorang pakar " $Y a$ Tuhan Kami, tiadalah Engkau menciptakan ini dengan sia-sia Maha Suci Engkau, maka peliharalah Kami dari api neraka". (QS. 3: 191). Suatu zikir yang berlandaskan kesadaran dan pengakuan kebesaran-Nya yang tiada taranya dan lebih menyentuh hati serta membekas. Dan secara mistis zikir yang demikian inilah yang menimbulkan rasa kepercayaan (iman) yang besar terhadap Allah. Percaya kepada Allah dengan wahyu melahirkan tashdiq, percaya kepada-Nya dengan melihat alam semesta khususnya diri manusia (mencakup struktur tubuh dan sifat-sifatnya) menimbulkan ma'rifat. Hal ini disinyalir dengan "khalaqal 
insana min 'alaq". Dengan demikian Man 'arafa nafsah faqad 'arafa rabba "Siapa yang tahu dirinya niscaya akan tahu Tuhannya".

Terkadang kepakaran seseorang dalam suatu disiplin menimbulkan rasa takabbur atau sombong, dan Allah sudah mengetahui akan hal tersebut sehingga Ia berfirman pada ayat selanjutnya dalam al-Alaq “jadilah kamu seorang pakar yang lebih tahu dari yang lain dan dimuliakan orang lain, namun ingat Tuhanmu itu lebih mulia darimu. (Q.S. 97:3). Jika kita menjasadkan esensi Tuhan (antromorphosis), dibaratkan kesombongan adalah baju Tuhan dan hanya layak dipakai oleh-Nya dan barang siapa memakai baju kesombongan tersebut berarti telah menelanjangi Tuhan di depan makhluk-Nya. Siapa yang tidak marah kalau ditelanjangi didepan khalayak?

\section{Khatimah}

Dengan demikian, kata iqra selain mencakup perintah belajar dan menggeluti suatu bidang disiplin ilmu yang diminati, juga merupakan sarana untuk men-tauhidkan Allah dengan melihat dan mengamati hasil ciptaan-Nya. Hal ini sesuai dengan misi rasul di Mekkah yaitu pemberantasan penyembahan berhala dengan berlandaskan tauhid.

Ditinjau dari sistem pendidikan yang berlangsung sejak lama yaitu adanya spesialisasi disiplin berbagai disiplin ilmu mulai dari pendidikan menengah hingga perguruan tinggi merupakan implementasi nilai-nilai Iqra yang sudah lama dicanangkan lewat wahyu pertama.

Wallahu' alamu bi as-Sawab. 